\title{
Brasilidade e publicidade: Como a publicidade ressalta a identidade brasileira em sua comunicação
}

\author{
Brazilianness and advertising: \\ How advertising highlights the Brazilian identity in \\ their communication
}

\begin{abstract}
Alhen Rubens Silveira Damasceno I alhenrubens@yahoo.com.br Mestrando em Ciências da Comunicação pela Escola de Comunicações e Artes da Universidade de São Paulo sob a orientação da Profa Dra Clotilde Perez. Publicitário formado pela Universidade Federal do Ceará. Bolsista do CNPq. Membro do GESC3 - Grupos de Estudos Semióticos em Comunicação, Cultura e Consumo da ECA-USP.
\end{abstract}

Resumo: A publicidade tem um papel fundamental na divulgação e legitimação da identidade brasileira. Ela se encarrega de mostrar e reforçar atributos que são facilmente identificáveis pela população e que essa se veja como possuidora de uma identidade única por causa da imensidão do país, das riquezas naturais e das várias culturas que aqui se hibridizam formando uma colcha de retalhos rica em costumes e tradiçóes próprios de um país miscigenado. Neste trabalho, pretendemos analisar como a imagem da identidade brasileira é percebida pela publicidade como um grande potencial gerador de significaçôes que levam para a aquisição do produto. Através da produção de sentido buscaremos analisar as peças publicitárias que reúnam a brasilidade como um signo a ser consumido pelo público.

Palavras-chave: Identidade brasileira; publicidade; percepção.

Abstract: Advertising plays a key role in disseminating and legitimizing the Brazilian identity. She takes care to show and reinforce the attributes that are easily identifiable by the population that sees herself as possessing a unique identity because of the vastness of the country, natural resources and the various cultures that are here hybridize forming a patchwork of rich own customs and traditions of a country interbred. In this work, we intend to analyze how the image of Brazilian identity is perceived by advertising as a potentially big generator of significations that lead to purchase the product. Through the production of meaning we will try to analyze the advertisements that meet the Brazilianity as a sign to be consumed by the public.

Keywords: Brazilian identity; advertising; perception. 


\section{Introdução}

Desde a chegada de Pedro Álvares Cabral ao Brasil temos um registro do nosso país como um paraíso na Terra, sempre exaltando a diversidade da natureza e sua exuberância, a abundância das águas e o colorido dos nossos animais. A claridade, o clima agradável e até mesmo os índios, que foram alcunhados de pacifistas e gentis como foram ressaltados, elementos que caracterizavam e embelezavam nossa terra. Com passar do tempo o Brasil cresceu, se tornou miscigenado, se modernizou e agora somos conhecidos mundialmente não só pelos aspectos naturais, mas também como o país do futebol, do carnaval, do samba, da sensualidade que exala nos corpos bronzeados, da alegria do nosso povo e da religiosidade sincrética.

São através dessas miscelâneas de características herdadas do índio, do branco e do negro que nasce uma identidade cultural brasileira, seus valores, seus costumes. E é nesse aspecto que a publicidade vem com todo o seu aparato sedutor, persuasivo para exaltar a brasilidade em suas campanhas. Ela se encarrega de expandir e difundir a questão da identidade brasileira para que os brasileiros de identifiquem com tais características e passem a adquirir os produtos/serviços que são imbuídos de uma brasilidade.

Este trabalho tem a finalidade de discutir como a publicidade insere em suas campanhas de mídia impressa, o fator brasilidade para agregar um valor positivo de reconhecimento do que somos e valorizar nossos aspectos simbólicos, para gerar a persuasão. $\mathrm{O}$ trabalho pretende mostrar a produção de sentido gerado pela publicidade através dos aspectos simbólicos da brasilidade. Neste quesito, estudaremos a semiótica peirceana que nos dará o suporte teórico no entendimento sígnico dos elementos que formam o Brasil e o sentido de identidade contido em Hall (2000) e sobre a identidade brasileira.

\section{A identidade e a identidade percebida}

Stuart Hall (2000) nos afirma que "as identidades nacionais não são coisas com as quais nascemos, mas são formadas e transformadas no interior da representação" (2000, p.45). Não nascemos com a nossa brasilidade, ela é fruto de um processo de formação que se iniciou com a chegada dos portugueses em terras brasileiras, com o contato do índio, com a vinda do negro e da miscigenação dessas três etnias. Desse contato, resultou uma hibridização das três culturas em uma identidade cultural brasileira. O que somos hoje é resultado dessa miscelânea, que ainda não parou por aí, estamos sempre em transformação. Como nos afirma Hall "as sociedades modernas são, portanto, por definição, sociedades de mudança constante, rápida e permanente” (idem, p.14), ou seja, no mundo globalizado em que vivemos as identidades culturais estáo sempre transitando. Elas dialogam com o passado e o presente, com outras identidades culturais, se misturam, se hibridizam, formando e transformando a todo tempo.

Hoje, fala-se muito em pós-modernidade, em trânsito constante. Estamos vivendo em uma época de profundas transformaçôes sociais, econômicas e culturais. A tecnologia nos garantiu uma aproximação com outros povos nunca vista antes na humanidade, o tempo e espaço passam a ser virtuais. 
Somos sujeitos inquietos, não temos uma identidade fixa, somos múltiplos em um único ser, assim como nos confirma Hall:

O sujeito pós-moderno não tem uma identidade fixa, essencial ou permanente. A identidade torna-se uma "celebração móvel": formada e transformada continuamente em relação às formas pelas quais somos representados ou interpelados nos sistemas culturais que nos rodeiam. É definida historicamente, $e$ não biologicamente. (HALL, 2000, p.12-13)

Para chegar a esse conceito, Hall, primeiramente, perpassou por três concepçóes de identidade: a do sujeito no Iluminismo, a do sujeito sociológico e a do pós-moderno. O sujeito do Iluminismo era absoluto, individualista, para ele, o "eu" era a razão, o central, sujeito consciente e da ação. Já o sujeito sociológico, era relacional, não tinha mais aquele centralismo como no sujeito iluminista. Esse tem na relação com outras pessoas um aspecto importante, pois a mediação do eu com a sociedade através de símbolos, da cultura e dos valores refletia a crescente complexidade do mundo e não cabia mais ao sujeito ser autônomo. $\mathrm{E}$ por último, vem o sujeito pós-moderno, plural. Como já havíamos falado, não compete a este a quietude de uma única identidade. A multiplicação das relaçóes simbólicas, dos sistemas de significaçôes fazem com que o sujeito expanda sua identidade e assuma diferentes identidades nos mais diversos lugares. É assim que Hall vê as mudanças das concepçóes das identidades na sociedade, pois estas, no fundo, não deixam de ser representaçóes sígnicas e sociais.

E como fica a nossa identidade cultural brasileira nessa avalanche de significaçóes que o mundo tem passado? Qual é a nossa imagem diante de nós mesmos, como nos enxergamos? Como a publicidade vê a nossa brasilidade e a transmite através do seu jogo representativo e simbólico?

Trindade (2003) nos fala que a construção de um projeto nacional ficou mais nítida a partir da chegada da família real ao Brasil em 1808, pois foi a partir daí que ocorreu um processo de desenvolvimento do nosso país, que antes colônia e com este fato, tornou-se sede do governo imperial português. $\mathrm{O}$ autor continua explicando que tal acontecimento histórico desencadeou um processo civilizatório no Brasil que se constituiu por uma mesclagem de etnias, culturas e valores que deram uma materialização peculiar ao sistema capitalista no Brasil.

No seu trabalho, Trindade analisa a contribuição do historiador Sérgio Buarque de Holanda (2000) na constituição da identidade cultural brasileira. Ele nos informa que o historiador percebeu que o Brasil se deve muito a formação do "homem cordial" retratado no livro "Raízes do Brasil" (1971) e da visão mítica do Brasil em "Visão do paraíso" (2000). O homem cordial constitui-se na relação entre a emoção e a razão, é uma forma de negociação para dar o famoso “jeitinho brasileiro" e conseguir driblar as adversidades da vida. Já no outro livro, é destacado o Brasil como um país do futuro com suas riquezas naturais.

Segundo Sorj (2000), o brasileiro desenvolveu, ao longo do seu processo histórico, algumas características acerca da sua maneira de se relacionar com o próximo e com as instituiçóes, tais como: a sociabilidade brasileira tem frágeis componentes cívicos, isto é, uma baixa identificação com os símbolos políticos 
do Estado e a noção de interesse público, devido à baixa escolaridade da população, o patrimonialismo e a impunidade; a sociedade brasileira é gregária, fundada na inserção em redes e, por extensão, na valorização dos contatos pessoais, o corporativismo; a sociedade brasileira é religiosa, majoritariamente católica, mas com sincretismo de origem africana e crescente presença das evangélicas; a sociabilidade brasileira apresenta práticas racistas, apesar de ser ideologicamente contrária ao racismo, vide o modo de exploração do trabalho que tivemos; a sociedade brasileira é voltada para o futuro; a sociedade contemporânea brasileira é autoritária, exibindo profundas desigualdades sociais, mas pouco hierárquica; a sociedade brasileira é violenta e, por fim, a sociedade brasileira é lúdica.

Essas características que foram afirmadas pelo sociólogo são bem distante daquilo que a propaganda passa em seus anúncios. Ela, a propaganda, subverte o olhar da realidade, faz com que a ludicidade do nosso povo seja um ponto crucial na nossa cultura coloca ricos e pobres no mesmo patamar nos anúncios sobre futebol e samba, o que suaviza o preconceito e mascara o elitismo proposto pelo autor. Nós preferimos a visão do paraíso do Sérgio Buarque de Holanda, que nos parece distante de problemas do nosso cotidiano. Preferimos a imagem de uma sociedade feliz, também retratada na publicidade. Antonio Arnoni Prado (2010) em sua "Apresentação a Visão do Paraíso" nos fala que:

A grande contribuição de Visão do Paraíso foi recompor o repertório de crenças e lendas
que, desde os primórdios da descoberta, associavam a imagem do Novo Mundo à ideia
- inspirada na teologia da Idade Média - de que o Paraíso terrestre, longe de ser um
conceito abstrato e inatingivel, era, ao contrário, um lugar que, apesar de distante, se
encontrava à disposição e ao alcance efetivos dos homens (PRADO in HOLANDA.
Visão do Paraíso, 2010, p.444)

Tal afirmação de Prado confirma o imaginário do colonizador quando viu a nossa terra, e inspira a publicidade a fazer o mesmo. O paraíso, a terra promissora, tudo isso é destacado pela publicidade na hora de ressaltar as qualidades brasileiras em suas campanhas.

Holanda (1971) em seu livro "Raízes do Brasil" argumenta sobre a maneira hospitaleira do povo brasileiro, sua cordialidade que é um traço marcante na nossa identidade e que é significativamente explorada pelos anúncios publicitários. Somos um povo alegre, emotivo, fazedor fácil de amigos, ou seja, um povo que desconhece a falta de sensibilidade para com o próximo. Até as rixas, no caso com os "hermanos argentinos" são em tons de piada, chacota, nada que não seja na base do humor, do risível. Holanda nos fala que

O desconhecimento de qualquer forma de convivio que não seja ditada por uma ética de fundo emotiva representa um aspecto da vida brasileira que raros estrangeiros chegam a penetrar com facilidade. Eé tão característica, entre nós, essa maneira de ser, que não desaparece sequer nos tipos de atividade que devem alimentar-se normalmente da concorrência. Um negociante da Filadélfia manifestou certa vez a André Siegfried seu espanto ao verificar que, no Brasil como na Argentina, para conquistar um freguês tinha necessidade de fazer dele um amigo (HOLANDA, 1971, p. 109). 


\section{A imagem da brasilidade}

Santaella (2010) nos esclarece sobre o que é imagem. Primeiramente, ela nos explicita que o mundo das imagens se divide em dois: o primeiro é o das imagens como representaçôes visuais tais como: desenhos, pinturas, gravuras, fotografias, as imagens televisivas, as cinematográficas etc. e esse tipo de imagem são objetos materiais. O segundo é o imaterial das imagens em nossas mentes aparecendo nas formas de visôes, fantasias, imaginaçóes, ou seja, as representaçóes mentais.

No caso da identidade cultural brasileira, a publicidade se encarrega de pegar as imagens visuais, reais, os signos que representam esse campo visual que nos rodeia, no caso, a brasilidade, e a transforma em um atrativo espetacularizado, por meio de seus mecanismos persuasivos. Em nossa mente ficam os reflexos de uma fantasia, imaginaçáo bem maior do que aquilo que se apresenta na vida real. A publicidade nos seduz e nos leva a um mundo idealizado de produto das imagens reais hiperbolicamente apresentadas nos anúncios.

Santaella, citando os ensinamentos de Peirce, nos afirma que o estudioso define representar como "estar para, quer dizer, algo está numa relação tal com um outro que, para certos propósitos, ele é retratado por uma mente como se fosse aquele outro" (2010, p. 17). Assim faz a publicidade, ela reafirma em suas campanhas que a representação do bem estar, do conforto, do status é tão verossímil como se fosse a coisa real representada e não uma concepção melhorada da realidade.

Um exemplo dessa representação da brasilidade está na marca Brasil ${ }^{1}$, confeccionada a pedido do Ministério do Turismo. O conceito de brasilidade existente no manual da marca e percebido pelos designers é de que o Brasil é um país sinuoso, curvilíneo, alegre, luminoso, brilhante, colorido, moderno, mestiço, híbrido. A marca tenta conceber todos os aspectos citados para que nos sintamos representados por essa marca Brasil e que a nossa imagem seja difundida mundialmente.

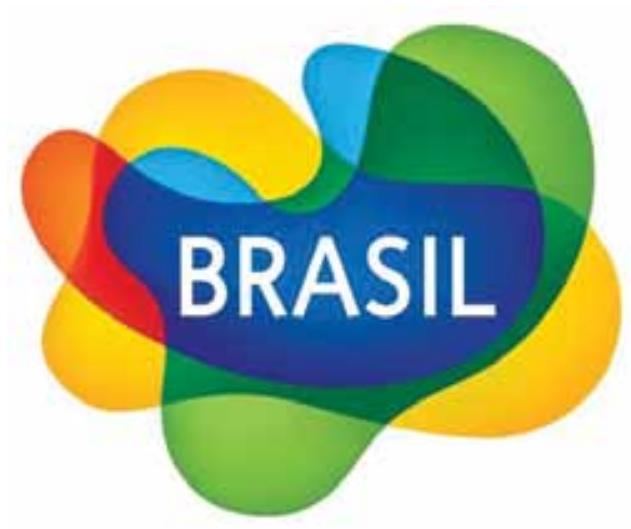

\section{Sensacional!}

Figura 1: Marca Brasil 


\section{O que os signos querem dizer sobre a brasilidade}

Neste tópico, discutiremos a semiótica peirceana e como ela pode nos auxiliar na produção de sentido das campanhas publicitárias que realçam a brasilidade. Quais os elementos típicos que o Brasil possui e que são identificáveis nas peças?

De acordo com Santaella (2002, p. 59), a semiótica peirceana “é a teoria de todos os tipos de signos, códigos, sinais e linguagens". Portanto, ela nos permite compreender palavras, imagens, sons em todas as suas dimensôes e tipos de manifestaçóes. Perez (2004) nos traz mais uma definição para melhor compreendermos a semiótica. Ela nos explicita que "entende-se por semiótica o estudo dos signos, ou melhor dizendo, estudo da ação dos signos, ou semiose. Concebemos signo como 'tudo aquilo que representa algo para alguém” (Perez, 2004, p. 140).

A semiótica estuda os processos comunicacionais, já que partimos da premissa que não existem mensagens sem signos que, por sua vez, não há comunicação sem mensagem. Tais processos comunicativos podem ser divididos em três faces a saber: a significação ou representação, a referência e a interpretação das mensagens.

$\mathrm{Na}$ face da significação, relativa ao signo, Santaella (2008) nos explicita que a análise semiótica nos permite explorar o interior das mensagens em três aspectos: primeiro - a qualidades e sensorialidade de suas propriedades internas (cores, linhas, formas etc.); segundo - mensagem na sua particularidade, no seu aqui e agora, contexto; terceiro - àquilo que a mensagem tem de geral, convencional, cultural.

As cores, na publicidade, são bastante exploradas em relação ao Brasil, além das cores da bandeira (verde, amarelo, azul e branco) outras como o vermelho e o laranja são muito utilizadas para dar uma ideia de calor, luz, sensualidade, alegria. Além de serem cores típicas das frutas tropicais cítricas.

$\mathrm{Na}$ face da referência, aqui a cargo do objeto, a análise semiótica nos permite compreender aquilo que as mensagens indicam, aquilo a que se referem ou se aplicam. Três aspectos: primeiro, sugestivo, metafórico; segundo, poder denotativo, capacidade de indicar algo que está fora da mensagem; terceiro, representar ideias abstratas e convencionais, culturalmente compartilhadas.

$\mathrm{Na}$ face da interpretação, em relação ao interpretante, a análise semiótica nos habilita a examinar os efeitos que as mensagens podem despertar no receptor. Três tipos: emocional, sentimento mais ou menos definido; segundo, efeitos reativos, o receptor é levado a agir em função da mensagem recebida; terceiro, mental, quando a mensagem leva o receptor a refletir.

Mas, o que viria a ser o signo na sua acepção peirciana? Para isso recorreremos mais uma vez aos ensinamentos da estudiosa do legado de Peirce, Santaella. Ela nos informa que signo "é qualquer coisa, de qualquer espécie que representa uma outra coisa, chamada objeto do signo, e que produz um efeito interpretativo em uma mente real ou potencial, efeito este que é chamado interpretante do signo" (Santaella, 2008, p.8). 

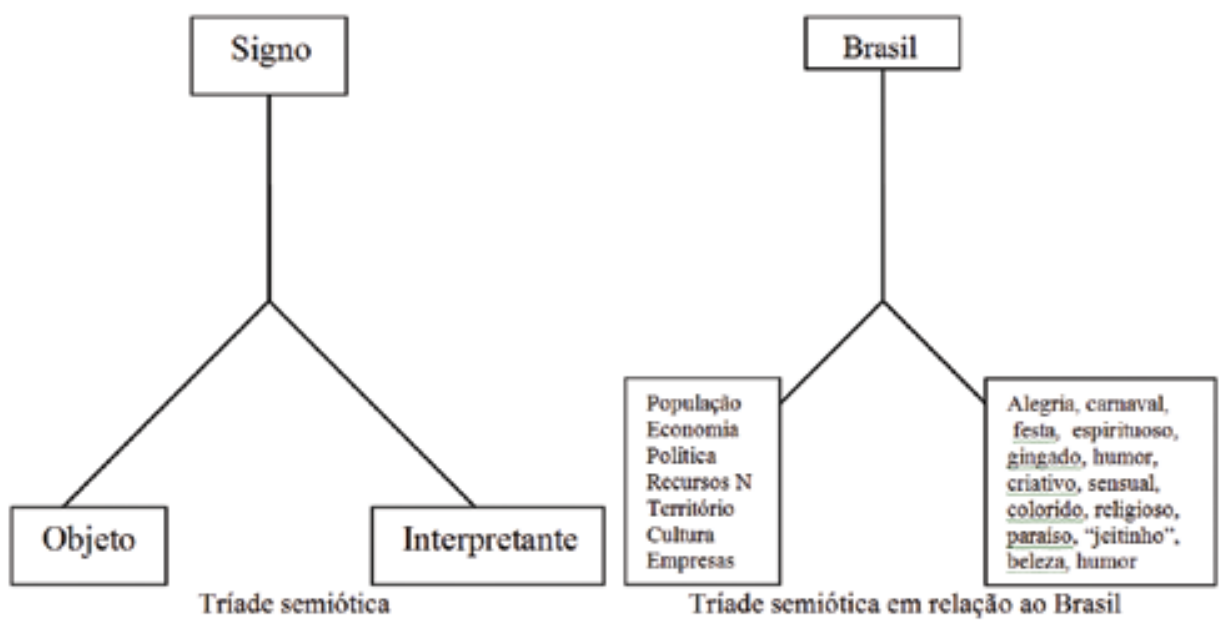

Por ser triádico, o signo permite uma abordagem em três faces. A face da relação do signo com ele mesmo. A face do signo em relação ao seu objeto no tocante a significação e, por fim, a face da relação do signo com o interpretante que é chamada de face da interpretaçáo, onde de acordo com Perez (2007) estão incluídos os efeitos de sentido (interpretantes) e a recepção (intérpretes). Mas, antes de analisarmos as faces com uma melhor precisão, vamos passar pelas categorias fenomenológicas que Peirce enumerou.

\section{Categorias fenomenológicas}

De acordo com Peirce (1977) existem três categorias fenomenológicas que nos aparecem à mente, ou seja, o fenômeno pode ser qualquer coisa que nós percebemos, que nos atinge e como nós apreendemos esse fenômeno. Tais fenômenos foram classificados como: primeiridade, secundidade e terceiridade. Nesse primeiro, o fenômeno está relacionado ao acaso, à possibilidade, ao sentimento, é mais emocional, nos toca o sensível. Quando o fenômeno nos vem à mente, podemos decompor e identificar os elementos, aqui, estamos raciocinando, ligando os elementos, as ideias, esse momento é chamado de secundidade. Já na terceiridade, temos a interpretação do fenômeno. Segundo Peirce,

Em toda relação triádica genuina, o Primeiro Correlato pode ser considerado como
aquele que determina, sob certo aspecto, o Terceiro Correlato, e as relaçóes triádicas
podem ser divididas conforme essa determinação do Terceiro Correlato tiver alguma
qualidade, ou estiver em alguma relaçáo existencial para com o Segundo Correlato
ou estiver em alguma relaçáo de pensamento para com o Segundo, por alguma razáo.
Um Representâmen é o Primeiro Correlato de uma relação triádica sendo o Segundo
Correlato denominado seu Objeto e o possivel Terceiro Correlato sendo denominado
seu Interpretante (PEIRCE, 1977, p.51)

Para Peirce (1977 p.51), entre as infinitas propriedades materiais, substanciais etc. que as coisas têm, há três propriedades formais que lhes dão capacidade para funcionar como signo: sua mera qualidade, sua existência, quer dizer, o simples fato de existir, e seu caráter de lei. 


\section{O signo em relação a ele mesmo}

O modo como o signo se apresenta pode ser de três formas, pois o signo em relação a si próprio é pura e, simplesmente, uma possibilidade qualitativa. Pois podemos afirmar, de acordo com as consideraçóes de Peirce, que tudo pode ser signo quando se trata de uma qualidade, em relação a sua existência, tudo é signo, e por último, tudo deve ser signo por causa de lei.

Se o que rege o signo for uma qualidade, como por exemplo, cores, linhas, formas, brilho, volume etc. Esses aspectos são capazes de despertar as emoçôes, e de acordo com a classificação semiótica, são chamados de quali-signos. Já em relação aos aspectos funcionais com uma concretude, uma relação do aqui e do agora em uma determinada situação contextual que se mostra a nossa percepção, estamos falando dos sin-signos da mensagem. E por último, os legi-signos podem ser analisados dentro de uma mensagem no seu caráter geral de algo que pertence a uma classe de coisas. $\mathrm{O}$ habitual, a lei, o convencional são características que determinam o legi-signo.

\section{O signo em relação ao objeto}

As mensagens podem ser analisadas em relação ao objeto, pois como nos explicita Santaella "Se o fundamento é um quali-signo, na sua relação com o objeto, o signo será um ícone; se for um existente, na sua relação com o objeto, ele será um índice; se for uma lei será um símbolo" (Santaella, 2008, p.14). Podemos, mais uma vez, ter uma análise em três níveis: o nível icônico, o indicial e o simbólico. O ícone representa o objeto por meio das qualidades, ele evoca o sensorial, o qualitativo, pois o que ele exibe se assemelha a uma outra qualidade, seja ela na forma de cores, luminosidade, texturas, movimentos etc. Nessa característica, os ícones têm um poder de sugestão muito acentuado, pois as qualidades podem ser um substituto de qualquer coisa que a ele lhe seja similar. Podemos notar que a propaganda se utiliza de certas metáforas. Ela é tipicamente icônica, em suas campanhas para dar alcunhas ao Brasil como "o país do futebol”, "o país do carnaval", "o país da alegria" dentre outras. Esse tipo de iconicidade sugere qualidades da identidade brasileira que é perpetuada pela publicidade, não só nacional, mas mundial. Vide quando a seleção brasileira de futebol joga pelo mundo afora vestindo o uniforme de cor amarela e como esse mote é transformado em publicidade do próprio país.

No índice, a relação é direta e se trata de existentes que se conectam com o objeto em uma relação casual, existente no mundo real. No índice, o que ele indica, não dá margem para outras interpretações, ou seja, ele não é ambíguo. São exemplos de índices, a febre de um paciente - que pode ser interpretada como um mal funcionamento de um órgão ou, uma inflamação - e uma pegada na areia, que indica que alguém ou algum animal esteve por perto. $\mathrm{O}$ índice, na publicidade, é explorado de uma forma metonímica, ou seja, a parte 
pelo todo que é mostrada, principalmente, nas propagandas que retratam a imensidão do país. Riquezas naturais e culturais tais como o Páo de Açúcar, que se localiza no estado do Rio de Janeiro, e que identifica todo o Brasil, assim como o Cristo Redentor, a Avenida Paulista, as praias do litoral nordestino, a floresta Amazônica etc. Apesar de indicarem pontualmente um único lugar, já estão tão enraizados em nossas mentes que quando vimos partes dessas paisagens identificamos um todo chamado Brasil.

Já o símbolo é regido por uma relação convencional, uma lei, um acordo. Nele, não há uma relação de similitude - como no caso do ícone - e nem de complementaridade, como o índice. O símbolo é livre para exercer sua potencialidade em relação ao objeto, graças à sua ação arbitrária e o poder de representar ideias abstratas. São exemplos de símbolos os logotipos das empresas, as palavras etc. O simbólico pode ser identificado na sensualidade que é um aspecto bastante explorado na publicidade, sempre mostrando corpos bem torneados e bronzeados pelo sol dos trópicos, na alegria e no bom humor dos brasileiros e no seu famoso "jeitinho" para driblar as adversidades da vida.

\section{O signo em relação ao interpretante}

De acordo com Perez "o interpretante diz respeito às imagens mentais que determinam a significação do signo" (Perez, 2004, p. 157). Seguindo a lógica triádica do modelo peirceano, o interpretante dinâmico (há outras possibilidades para o interpretante) se divide em três aspectos: emocional, funcional e lógico.

No interpretante emocional, o efeito do signo é puramente sentimental. No aspecto do interpretante funcional há uma reação sobre o efeito produzido levando o intérprete à ação. No caso da publicidade, a ação é voltada para o ato da compra. $\mathrm{O}$ indivíduo teve um dispêndio de energia para realizar a ação, seja ela motora ou intelectual. $\mathrm{O}$ interpretante lógico tem uma regra interpretativa internalizada pelo intérprete do signo. Aqui, a interpretação tem um caráter lógico, que pode vir a se tornar um hábito, como na fidelização de um produto.

A publicidade que se utiliza dos elementos de brasilidade pretende formar uma imagem do Brasil como sendo o "paraíso na Terra”, o Éden. E é através desses aspectos que emociona o auditório com todo um repertório de pertencimento, reforçando a ideia de que o brasileiro é tudo isso que está sendo mostrado nas campanhas: um povo alegre, forte, vibrante. Assim junto com o produto anunciado, podemos vivenciar juntos essa brasilidade cheia de entusiasmo pela vida.

\section{A brasilidade nos anúncios}

Passaremos, agora, a analisar a presença da identidade cultural brasileira nas peças publicitárias de mídia impressa. Como a brasilidade é mostrada nos 
anúncios, quais os elementos de significação são gerados pela publicidade para conciliar os aspectos da brasilidade com o produto ou serviço anunciado.

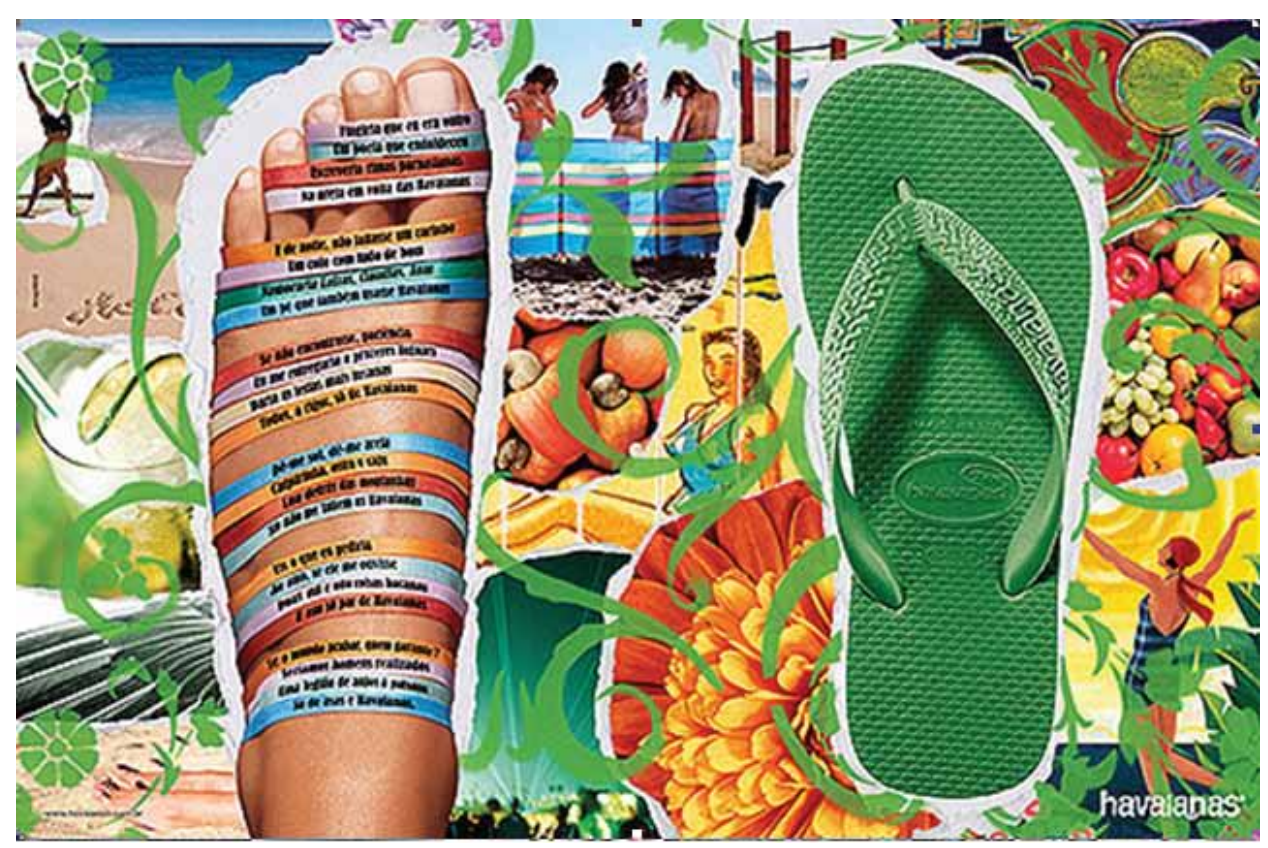

Figura 2: anúncio das sandálias Havaianas (2008)

O anúncio duplo produzido pela agência AlmapBBDO para a mídia impressa das sandálias havaianas, mostra claramente alguns elementos da cultura brasileira. A campanha pretende ressaltar traços da brasilidade que podemos analisar por partes: primeiramente, um pé com fitinhas coloridas e outro com a sandália. As fitinhas coloridas são frequentemente associadas às pulseirinhas religiosas que os devotos amarram nos pulsos, fazendo um pedido, e só a tiram quando esta se quebra. Isso nos dá uma alusão da religiosidade do povo brasileiro. A sandália havaiana da cor verde nos remete ao verde que representa as matas na nossa bandeira nacional. As cores quentes, amarelo, laranja e vermelho estão associadas às frutas típicas do Brasil (caju, acerola, laranja, maçã) e também a diversidade da natureza representada pelas flores. Todos esses elementos passam uma ideia da tropicalidade do nosso país.

Depois podemos notar a sensualidade do nosso povo, que fica por conta dos corpos femininos em trajes de banho. Notamos, também, a sensação de liberdade sugerida pela praia e o homem "plantando bananeira" nesse mesmo ambiente. Outro aspecto da brasilidade é a famosa caipirinha, uma bebida típica brasileira à base de cachaça, limão e açúcar. É a partir de recortes da nossa identidade cultural que a propaganda das sandálias havaianas pretende realçar esse atributo de um país tropical, alegre, excitante, cheio de diversidades e que o produto, as sandálias havaianas, está inserido dentro desse contexto da brasilidade, pois ela também faz parte do repertório cultural, assim como os outros elementos sugeridos na campanha. 


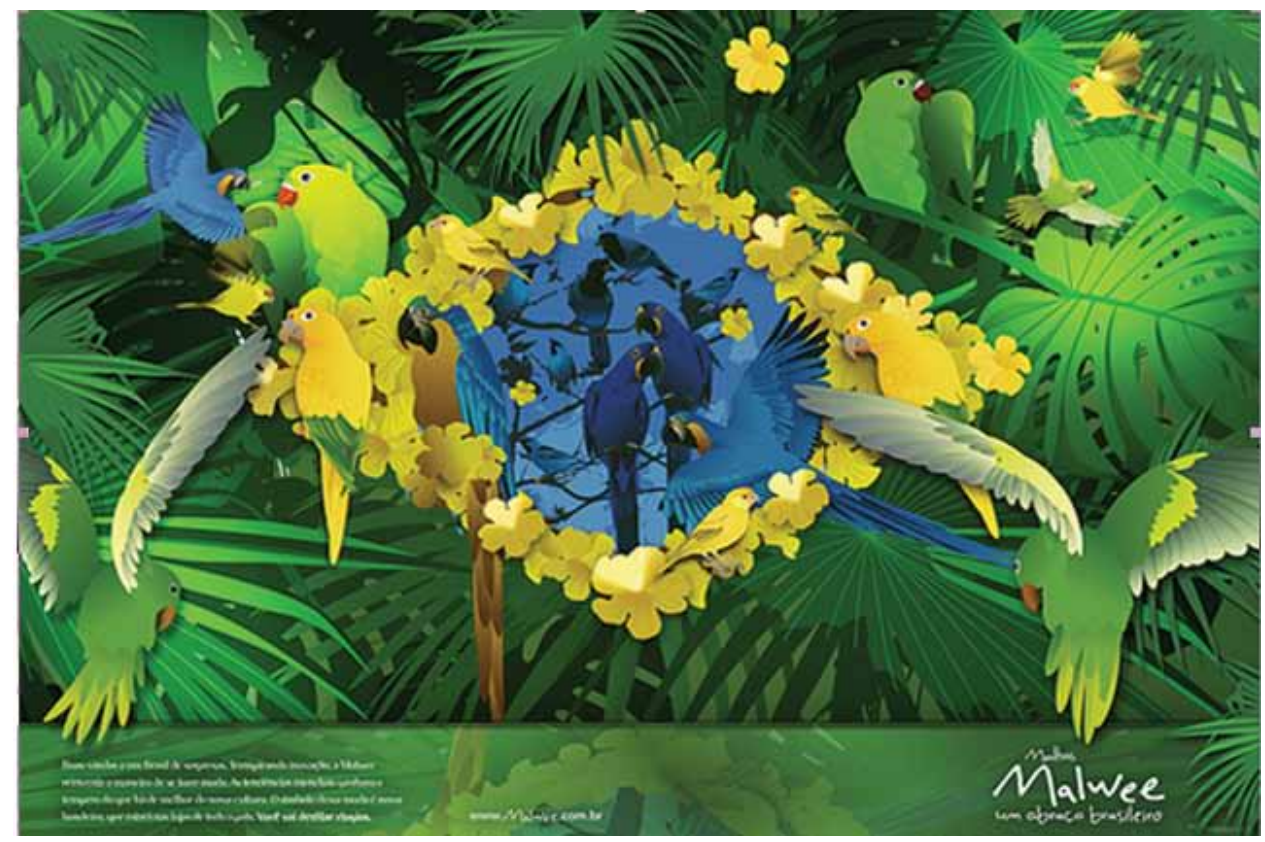

Figura 3: anúncio das malhas Malwee (2009)

O anúncio das malhas Malwee (2009) criado pela agência CMC (Central de Marketing de Comunicação) que tem como slogan "Malwee um abraço brasileiro", deixando de lado o antigo slogan da marca, "Malwee gostosa como um abraço". Ele traz em sua composição a bandeira brasileira formada pelos elementos da nossa fauna e flora, com o verde retratando as matas. Nesta parte do anúncio há um destaque para as palmeiras e também para aves como o papagaio e a jandaia. O losango amarelo está representado pelas ararajubas, ave símbolo do Brasil e por flores estilizadas. O azul fica por conta da arara azul, pássaro que está em processo de extinção, e que neste caso representa o céu. A propaganda, além de ressaltar a diversidade natural brasileira com cores que são tão arraigadas em nossa cultura, nos dá uma sensação de liberdade, de um resgate da natureza. Percebe-se mais uma vez que a noção de paraíso da diversidade aparece através da composição do anúncio.

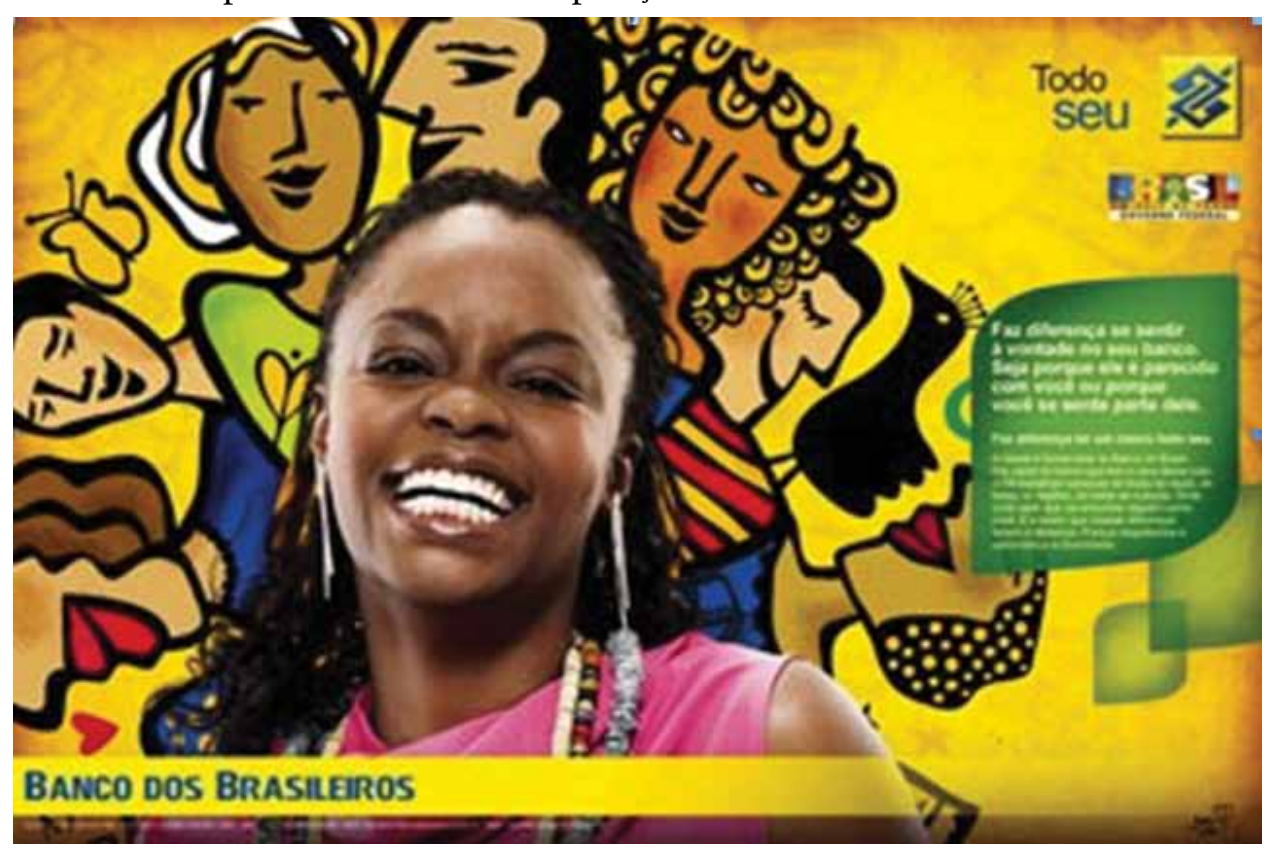

Figura 4: anúncio Banco do Brasil (2009) 
Esse anúncio produzido pela agência Master (2009), diferentemente dos outros dois analisados, traz a diversidade étnica do povo brasileiro através da miscigenação do índio, branco e negro, que tanto contribuíram para a formação do povo brasileiro. Essa mistura é representada pelos desenhos estilizados que lembram a xilogravura. $\mathrm{O}$ anúncio pretende passar que, apesar de sermos diferentes na composição (índio, negro, branco, mulato), somos todos brasileiros assim como o Banco do Brasil, um banco brasileiro feito para os mais diferentes tipos de brasileiros. Também podemos notar a simpatia através do sorriso da mulher que está em primeiro plano. Esse sorriso evoca uma alegria que é conhecida por todos nós e pelos turistas que vem nos visitar, a espontaneidade e o bom humor dos brasileiros.

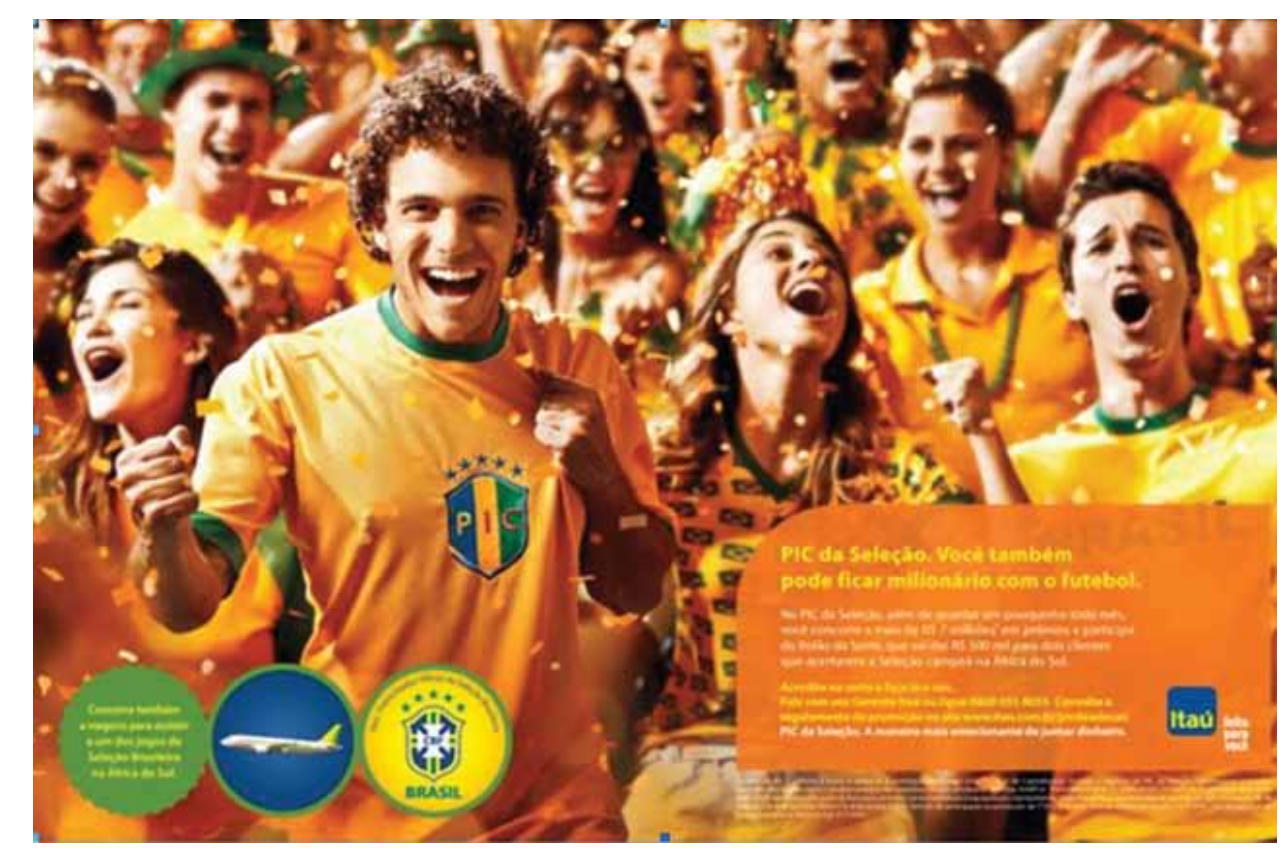

Figura 5: anúncio Banco Itaú (2010)

E por último, o anúncio "PIC da seleção" criado em 2010 pela agência DM9DDB para o banco Itaú que consegue juntar a paixão do torcedor brasileiro - já que o Brasil é conhecido como o "país do futebol" - com a alegria de festejar. Notamos que os torcedores estão eufóricos com a seleção brasileira de futebol. Todos estão vestidos com camisas amarelas que fazem uma alusão ao uniforme "canarinho", como é conhecida a nossa seleção. Notamos nesse anúncio que o futebol está muito parecido com o carnaval, as pessoas se fantasiam com chapéus coloridos, usam adereços para se enfeitarem, extravasam as alegrias como no carnaval. $\mathrm{O}$ anúncio consegue juntar duas grandes celebraçôes da nossa cultura: o futebol e o carnaval. Apesar de não mencionar a festa, subentendesse pelo nosso histórico que quando o Brasil participa dos jogos da copa do mundo e vence seus adversários a comemoração do nosso povo nos permite dizer que é uma espécie de carnaval fora de época. Assim temos uma expressão simbólica de total euforia pela seleção e a ideia de que o banco Itaú apóia e vibra com os torcedores, pois na camisa do torcedor em primeiro plano estáo estampadas as cinco estrelas, o pentacampeonato. Logo abaixo, no lugar do escudo da CBF, está o do PIC (Plano Itaú de Capitalização), simbolizando que o PIC é tão bom quanto a seleção brasileira e, por isso, é de total confiança. 
Pode-se apreender que quem tem pique para torcer pela seleção brasileira tem que ter PIC como um investimento para a vida.

\section{Considerações Finais}

A publicidade, com o seu resgate da identidade brasileira, se apropria de elementos constituintes da brasilidade para mexer com imaginário da população. Nas peças analisadas podemos inferir que a publicidade se cerca dos estereótipos da brasilidade, ou seja, da miscigenação, dos recursos naturais, da alegria do nosso povo, do futebol, do festejo, para poder dizer que o Brasil é um país cheio de entusiasmo. Para afirmar que o nosso povo é feliz e tem qualidades que nenhum outro povo possui. Que sabe aproveitar a vida com o que a de melhor para ser vivido.

A publicidade enxerga esse mote da brasilidade com um grande potencial para inserir produtos/serviços que realcem os atributos brasileiros. Com a identificação dos produtos com o Brasil, os brasileiros estão adquirindo não só um produto ou serviço qualquer e sim uma possibilidade a mais de pertencimento. É a imagem do ser brasileiro que está sendo consumida através da significação da propaganda.

A publicidade, nesse caso, é hiperbólica ao realçar os aspectos positivos de uma vivência com o produto ou serviço adquirido. Aqui, tratamos da brasilidade, e é eufemística quando se trata de suavizar alguns possíveis problemas que a propaganda possa ter em relação com o seu público. No caso das propagandas analisadas, não se viu nenhum aspecto que pudesse ir ao encontro de tais problemas, sejam eles econômicos, sociais e políticos, pois é sabido que o Brasil enfrenta problemas nessas áreas. Na publicidade, o mundo é idealizado, sem problemas e só com soluções. É mítico e, principalmente, edulcorado.

\section{Referências Bibliográficas}

HALL, Stuart. A identidade cultural na pós-modernidade. Rio de Janeiro: DP\&A, 1999.

PEIRCE, Charles. Semiótica. São Paulo: Perspectiva, 1977.

HOLANDA, Sérgio Buarque. Raízes do Brasil. Rio de Janeiro: Editora José Olympio, 1971.

. Visão do paraíso. São Paulo: Brasiliense; Publifolha, 2010.

PEREZ, Clotilde. Signos da marca. Expressividade e sensorialidade. São Paulo: Pioneira Thompson Learning, 2004

. Universo Sígnico do Consumo: o sentido das marcas. Tese

de Livre docência. Escola de Comunicaçóes e Artes. Universidade de São Paulo, 2007

SANTAELLA, Lúcia. A teoria geral dos signos: como as linguagens significam as coisas. São Paulo: Pioneira, 2000 
. Semiótica aplicada. São Paulo: Cengage Learning, 2008

.Lúcia: NÖTH, Winfried. Imagem: cognição, semiótica, mídia. São Paulo: Iluminuras, 2010

SORJ, Bernardo. A nova sociedade brasileira. Rio de Janeiro. Jorge Zahar Editor, 2000

TRINDADE, Eneus. "Brasil, mostra a tua cara": publicidade e identidade cultural brasileira na transição secular. Tese de Doutorado. Escola de Comunicaçôes e Artes. Universidade de São Paulo, 2003

http://www.turismo.gov.br/turismo/multimidia/logotipos_marcas/ marca_brasil.html

\section{Notas}

1. A Marca Brasil é uma marca de difusão e promoção do Brasil como destino turístico no mercado nacional e internacional. Ela deverá ser utilizada em açóes de promoção no Brasil e no exterior. 